\title{
Investigação Participativa com Crianças / Participatory Research with Children
}

https://doi.org/10.21814/uminho.ed.36.37 



\section{Investigação Participativa com Crianças}

Este texto fornece uma breve visão geral sobre algumas das raízes dos métodos de investigação participativa com crianças. Termina com a discussão sobre a necessidade de desconstruir a ideia de participação, que significa literalmente "tomar parte em", e haver um maior envolvimento e debate em torno deste termo. A participação tem sido referida como tendo o potencial, tanto para a tirania quanto para a transformação. Até que ponto os "métodos" podem ser designados por participativos depende, portanto, da natureza do processo ou metodologia adotados ser ou não participativa, bem como se, nas normas sociais para a infância que balizam a ação das crianças e os jovens, a noção de participação está suficientemente integrada para que crianças e jovens sejam levados a sério.

Existem diferentes raízes nos métodos participativos com crianças.

Esta é uma área em que os profissionais de intervenção no sector da infância têm tido um contributo significativo para o desenvolvimento de abordagens e métodos participativos em paralelo com raízes mais académicas. O contexto político mais amplo da Convenção das Nações Unidas sobre os Direitos da Criança (ONU, 1989) específica três P: proteção, provisão e participação. $O$ Artigo $12{ }^{\circ}$ da Convenção tem sido citado, com frequência, para justificar a aplicação de abordagens e métodos participativos de forma a garantir que crianças e jovens possam opinar sobre questões relevantes para as suas vidas. Outros artigos têm sido igualmente citados como relevantes, como o Artigo $2 .^{\circ}$, sobre o "superior interesse da criança", e o Artigo $15^{\circ}$, sobre a liberdade de associação das crianças (ver Johnson et al., 1998). Em resposta à $C D C$, muitas agências não-governamentais e alguns departamentos governamentais na área da infância e juventude começaram a colocar em prática medidas que visavam concretizar o direito de as crianças e jovens participarem das decisões que afetam as suas vidas. Uma ampla gama de diferentes métodos, como desenho, visuais, narrativas, movimento e brincadeira, foram desenvolvidos para envolver crianças de diferentes idades nas pesquisas, nos planos de intervenção e de avaliação. Alguns desses trabalhos, especialmente internacionalmente, foram guiados por académicos, mas também por profissionais de diferentes áreas de intervenção que se foram dedicando à investigação (por exemplo, ver Boyden \& Ennew, 

CHILDREN

1997). Muito progresso foi alcançado ao longo das décadas de 1980,1990 e 2000 para ouvir mais as crianças e jovens. Contudo, mais recentemente, a questão que se levanta é a de saber até que ponto as evidências e as suas vozes são, de facto, não só ouvidas como também postas em prática.

Paralelamente, na academia, os métodos participativos emergiram na Geografia Humana, na Antropologia e na Sociologia da Infância. Geógrafos humanos e urbanistas consideram a participação de crianças nos seus estudos para mapear e modelar os espaços e lugares onde viviam e brincavam (por exemplo, Hart, 1979; Lynch, 1979). À aplicação mais popular de abordagens etnográficas e criativas seguiu-se o reconhecimento de que as crianças eram sujeitos, em vez de objetos de pesquisa. Em especial, através do recurso à observação e ao acompanhamento da vida quotidiana das crianças, incluindo a recolha de informação através de desenhos, de narrativas e entrevistas abertas, com instruções para as incentivar a expressar as suas opiniões. Exemplos de estudos pioneiros que surgiram utilizando métodos etnográficos com crianças são, por exemplo, o trabalho de Reynolds, em 1991, de Nieuwenhuys, em 1994, e de Johnson et al., em 1995. Os trabalhos iniciais da Sociologia, e a partir de uma perspetiva educativa, forneceram métodos etnográficos, através do desenho e da brincadeira, suscitando aspetos particularmente interessantes paralelamente ao levantamento de questões éticas em pesquisas com crianças (por exemplo, ver Corsaro, 1997; Christensen \& James, 2000). Outras disciplinas, como a Psicologia do Desenvolvimento, continuaram a tratar as crianças como objetos de pesquisa até recentemente, reconhecendo que as crianças têm preocupações e perspetivas válidas sobre seu bem-estar físico e psicológico à medida que crescem em contextos diferenciados. Alguns estudiosos do desenvolvimento infantil têm contribuído consistentemente para discursos sobre a melhor forma de se ouvir as crianças levando em consideração as suas capacidades em desenvolvimento (por exemplo, Woodhead \& Montgomery, 2002).

Pesquisas desenvolvidas com crianças e jovens em fase posterior à aprovação da CDC passaram a tratá-los como participantes ativos. Em processos de desenvolvimento internacional mais abertos, no entanto, as suas contribuições para o desenvolvimento da comunidade eram, às vezes, invisíveis ou ignoradas. Portanto, outra raiz dos métodos participativos com crianças passa por integrar os direitos da criança em processos de "pesquisa participativa em ação" realizada com adultos. Métodos participativos e criativos foram desenvolvidos em processos comunitários de pesquisa e investigação, largamente influenciados por filósofos como Paulo Freire. Uma família de métodos e "comunidades de prática" associaram-se sob o termo Avalia- 
ção Participativa (Rural) e, posteriormente, ao termo Aprendizagem e Ação Participativas, defendidos globalmente por diversos estudiosos, nomeadamente o Professor Robert Chambers (2012). Os métodos participativos incluíam mapeamento, recursos visuais esquemáticos e estruturados, narrativas fotográficas e artes, músicas e jogos mais criativos. Houve um discurso crescente ao longo da década de 1990 de que as perspetivas ou evidências das crianças eram frequentemente postas de lado ou ignoradas (Bartlett, 2001; Johnson \& West 2018). Embora outras questões sobre diferença tenham sido levadas em consideração nos processos conduzidos pela comunidade, examinando dinâmicas a partir das questões de género e de casta/ etnia, por exemplo, as crianças não foram necessariamente incluídas. Houve avanços combinando as aprendizagens a partir das diferentes raízes: métodos participativos e criativos foram desagregados segundo a idade dos participantes e desenvolvidos ainda mais com crianças e jovens (Chawla \& Johnson, 2004). Demorou tempo até que as abordagens participativas com crianças permeassem estudos, debates e processos de desenvolvimento internacional mais amplos, indo além daqueles focados em crianças que são vistas como vulneráveis por agências de financiamento, autoridades e investigadores. Entre estas áreas de foco específico estão as crianças em conflito com a lei, as crianças trabalhadoras, as crianças traficadas e as crianças migrantes.

Abordar métodos como sendo participativos requer examinar a metodologia, num sentido mais amplo, bem como os contextos políticos e institucionais nos quais são aplicados. Nas últimas décadas, houve várias tentativas de entender o que significa o termo "participativo". Em alguns aspetos, pode haver a ideia errada de falar sobre "métodos" participativos em vez de abordagens ou metodologias participativas. Na escada de Hart (1992), desenvolvida a partir da escada de participação de Arnstein, foram apresentados diferentes níveis de participação que incluíam a não participação, como é o caso da manipulação e tokenismo. A escada de Hart leva em consideração se as crianças despoletam as ideias e como são apoiadas nesse processo, incluindo os seus relacionamentos com adultos. Embora cercados de nuances e críticas, esses aspetos das relações intergeracionais e do modo como as ideias são formadas, apoiadas e postas em prática, são importantes quando se considera a necessidade de perceber até que ponto os processos são efetivamente participativos. 0 contexto em que os métodos são aplicados é outra questão crítica. Pode ser necessário tomar medidas para se navegar pelas normas sociais da infância, onde as crianças podem não ser ouvidas ou levadas a sério, e pela ética do seu envolvimento em pesquisas e intervenções. Neste âmbito, é ainda importante levar em consideração as 

CHILDREN

diferentes idades e os aspetos interseccionais de diferença e desigualdade (Christensen \& James, 2000; Johnson, Hart \& Colwell, 2016).

(Tradução de Marlene Schüssler D'Aroz)

\section{Participatory Research Methods with Children}

This section provides a brief overview of some of the different roots of participatory research methods with children. It ends with a discussion of the necessity to deconstruct the idea of participation, literally meaning to "take part", and to engage in the discourses around this term. Participation has been referred to as having the potential for both tyranny and transformation. Whether "methods" can be referred to as participatory, depends therefore on the extent to which the process or methodology in which they are applied is participatory and whether the social norms of childhood, children and youth can be navigated and understood so that they are taken seriously.

There are different roots in participatory methods with children.

This is an area in which practitioners have also contributed to the development of participatory approaches and methods in parallel with more academic roots. The broader policy context of the UN Convention on the Rights of the Children (UNCRC, 1989) specifies three Ps that include protection, provision and participation. Article 12 of the convention is often cited when participatory approaches and methods have been applied to give children and young people a voice in issues of relevance to their lives. Other Articles have also been cited as relevant, including Article 2 on the "best interests of the child" and Article 15 on children's freedom of association (see Johnson et al., 1998). In response to the UNCRC, many non-governmental agencies and some government departments that were child and youth focused responded to this right for children to participate in decisions that affected their lives. An expansive array of different drawing, visual, narrative, moving and play methods have been developed to engage children of different ages in research, plans for intervention and evaluation. Some of this work, especially internationally, has been guided by academics and practitioner researchers (for example see Boyden \& Ennew, 1997). Much progress has been made throughout the 1980s, 1990s and 2000s on raising the voices of children, and more recently questions have been asked about whether young people's evidence and voices are heard and acted upon. 
In parallel with academia, participatory methods emerged from human geography, anthropology and the sociology of childhood. Human geographers and urban planners engaged with children to map and model the spaces and places where they lived and played (for example Hart, 1979; Lynch, 1979). The more popular application of ethnographic and creative approaches followed from the recognition that children were subjects rather than objects of research, particularly drawing on observation of and participation in children's everyday lives, including drawing and narrative and open interviews with prompts to encourage children to express their opinions. Examples of early groundbreaking work occurring using ethnographic methods with children include work by, for example Reynolds 1991, Nieuwenhuys 1994, Johnson et al. 1995. Early work from within sociology and from an educational perspective provides particularly interesting ethnographic, drawing and play methods alongside ethical questions in research with children (for example see Corsaro, 1997; Christensen \& James, 2000). Other disciplines such as developmental psychology retained the view of children as objects of research until more recently, with the recognition that children have valid concerns and perspectives about their physical and psychological wellbeing as they grow up in different contexts. Some child development academics have consistently contributed to discourses about how to best listen to children, taking into account their developing capabilities, (for example Woodhead \& Montgomery, 2002).

After the UNCRC was approved, in research that was developed with children and youth, they started to be treated as active participants. In broader international development processes, however, children and young people's contributions to community development were sometimes invisible or ignored. Another root to participatory methods with children was therefore to integrate child rights into broader processes of "participatory action research" carried out with adults. Participatory and creative methods were developed in community-driven processes of research and inquiry that were influenced by philosophers such as Paulo Freire. A family of methods and 'communities of practice' associated themselves with the term Participatory (Rural) Appraisal (PAR/ PA) and later Participatory Learning and Action, championed globally by academics, notably Professor Robert Chambers (for example, see 2012). Participatory methods included mapping, diagrammatic and structured visuals, photo narratives and more creative arts, music and games. There was growing discourse through the 1990s that children's perspectives or evidence was often sidelined or ignored (Bartlett 2001; Johnson \& West, 2018). Whilst other issues of difference were taken into account in community - driven processes, for example examining dynamics due to 
gender and caste/ethnicity, children were not necessarily included. Inroads were made combining learning from these different roots: participatory and creative methods were disaggregated by participants' ages. These participatory action research methods were therefore further developed with children and young people (Chawla \& Johnson, 2004). It has taken time for participatory approaches with children to filter into broader international development studies, debates and processes, apart from those that focus on children who are seen as vulnerable by funders, authorities and researchers. These areas of specific focus include children in conflict with the law, child labourers, trafficked children and children on the move.

To refer to methods as participatory also requires an examination of the broader methodology, and political and institutional contexts within which they are applied. There have been various attempts through the past decades to understand what is meant by the term participatory. In some situations, it can be misleading to talk about "methods" as opposed to approaches or methodologies as being participatory. In Hart's ladder (1992), developed from Arnstein's ladder of participation, different levels of participation were expressed that included non-participation, such as manipulation and tokenism. Hart's ladder also takes into account whether children initiate ideas and how they are supported, including their relationships with adults. Although surrounded by nuance and critique, these aspects of intergenerational relationships and how ideas are formed, supported and acted upon, are important when considering the extent to which processes are participatory. The context in which methods are applied is also critical. Steps may need to be taken to navigate both social norms of childhood, where children may not be listened to or taken seriously, and the ethics of engaging children in research and intervention. Different ages and intersecting aspects of difference and inequality (Christensen \& James, 2000; Johnson, Hart \& Colwell 2016) must also be taken into account.

\section{Referências / References}

Bartlett, S. (2001). Children and development assistance: the need to re-orient priorities and programmes. Development in Practice, 11(1), 62-72.

Boyden, J. \& Ennew, J. (1997). Children in Focus - A Manual for Participatory Research with Children. Save The Children Sweden.

Chambers, R. (2012). Provocations for Development. Warwickshire: Practical Action Publishing. 
Chawla, L. \& Johnson, V. (2004). Not for children only: lessons learnt from young people's participation, Participatory Learning and Action, 50 (October), 63-72.

Christensen, P. \& James, A. (2000). Research with Children: Perspectives and practices. London: Routledge: Falmer.

Hart, R. (1992). 'Children's Participation: From tokenism to citizenship'. Innocenti Essays 4. Florence: UNICEF International Child Development Centre.

Hart, R. (1979). Children's Experience of Place. New York: Wiley.

Johnson V., Hart R. \& Colwell J. (2016). International Innovative Methods for Engaging Young Children in Research. In R. Evans, \& L. Holt (Eds.), Methodological Approaches: Geographies of Children and Young People (Vol. 2, pp. 335-356). Singapore: Springer.

Johnson, V., Hill, J. \& Ivan-Smith, E. (1995). Listening to Smaller Voices: children in an environment of change. Sommerset: ActionAid.

Lynch, K. (1979). Growing Up in Cities. Cambridge, Mass: MIT Press.

Reynolds, P. (1991). Dance, Civet Cat: Child Labour in the Zambezi Valley. London: Zed.

Woodhead, M. \& Montgomery, H. (2002). Understanding childhood: an interdisciplinary approach. London: Wiley. 